\title{
Righting Domestic Wrongs with Refugee Policy
}

\author{
Matthew Lindauer ${ }^{1}$ \\ Brooklyn College, City University of New York \\ Forthcoming in Critical Review of International Social and Political Philosophy
}

\begin{abstract}
Discriminatory attitudes towards Muslim refugees are common in liberal democracies, and Muslim citizens of these countries experience high rates of discrimination and social exclusion. Uniting these two facts is the well-known phenomenon of Islamophobia. But the implications of overlapping discrimination against citizens and non-citizens have not been given sustained attention in the ethics of immigration literature. In this paper, I argue that liberal societies have not only duties to discontinue refugee policies that discriminate against social groups like Muslims, but remedial duties to citizens who are in these social groups to adopt a more welcoming stance towards the groups that they are in. Further, I argue that a fitting way of adopting this more welcoming stance is to give refugees in these groups preferential treatment in asylum and resettlement.
\end{abstract}

KEYWORDS discrimination; domestic justice; Muslims; refugees; remedial duties

During the 2016 U.S. presidential campaign, Donald Trump Jr. notoriously tweeted an analogy between the Syrian refugee crisis and a bowl of Skittles. It read, "If I had a bowl of Skittles and told you just three would kill you, would you take a handful? That's our Syrian refugee problem." While this tweet directly suggested that some refugees were deadly, the domestic resonance of the statement, which was also clearly intended both by Trump Jr. and those who shared the tweet, was patently clear. Like many other public expressions that facially concern outsiders and the supposed risk to us of allowing them in, the tweet clearly had Islamophobic content that raised the question whether Muslim-Americans really belong in American society, or are "real Americans" at all. President Trump and his associates expended a

\footnotetext{
${ }^{1}$ Matthew Lindauer matthew.lindauer@brooklyn.cuny.edu
} 
great deal of effort fanning the flames of Islamophobia as a way of branding the Republican Party as the only American political party telling the truth about the threat of Islam, foreign and domestic.

The problem of targeting and denigrating domestic Muslim populations through rhetoric and policies that directly concern Syrian refugees is not unique to the U.S. According to the 2017 European Islamophobia Report (Bayraklı \& Hafez 2018), average public opposition to further migration in Europe is 55 percent, with a range of 41 percent in Spain to 71 percent in Poland. While these statistics may seem to speak only to the existence of generalized xenophobia, the report emphasizes the many instances in which right-wing politicians and parties in Europe have provoked Islamophobia in particular as a strategy for advancing their antimigrant agenda and increasing their support among voters. National governments in Poland, Hungary, and the Czech Republic have openly refused to accept Muslim refugees on the basis that they are a purported security threat. In 2016, then Polish Prime Minister Beata Szydlo openly stated that she would accept Christian refugees from Syria but not Muslims. After the Brussels attack of 2016, she changed her position and said she would stop taking refugees altogether out of concerns for national security. The average Polish citizen overestimates the percentage of the population that Muslims represent by roughly 70 times, believing them to be 7 percent of the domestic population when they are actually .1 percent. An Ipsos MORI survey in 2016 found a gap between public perception of domestic Muslim population size and reality in 40 countries, with people in the U.K. overestimating by three times on average and people in France by four times (Ipsos MORI 2016).

There are Muslim citizens within each of these societies to whom a very clear message is sent by these refugee policies and pronouncements regarding refugees. It is a distrustful and 
discriminatory message that is somewhat general and diffuse, but there are a number of specific claims that it can plausibly be interpreted as committed to. "They are not real Xs" (Americans, Poles, etc.), "They do not belong here," "If they were refugees, they would be treated with extra suspicion and/or denied entry," "If it was possible, some of their fellow citizens and political officials would try to deport them." In each case, the attitude expressed conflicts with what many have taken to be a core principle of domestic justice, the principle of equal respect for members. I will say more about this principle below, but it can be interpreted as the principle that a society's political institutions, policies, and members in their official capacities must treat all members of society with equal respect and, when applicable, must express equal respect for them.

It's the second requirement of this principle and the expressive content of refugee policy that I will focus on in this paper. The domestic significances of these policies and attitudes, I hold, have important implications for domestic justice that have yet to be given sustained attention in the ethics of immigration literature. Societies where members of particular social groups experience discrimination have duties to citizens in these groups to avoid furthering this discrimination by adopting refugee policies that exclude refugees in these groups. This point is a natural extension of prior work on the domestic resonance of immigration policy. ${ }^{1}$ But further, I will argue that these societies have remedial duties to these citizens to take a more actively welcoming stance towards these refugees, and a fitting way of adopting this stance is to give refugees in the relevant groups preferential treatment in asylum and resettlement. ${ }^{2}$

In focusing on these implications of the principle of equal respect for members, a core liberal principle of domestic justice, my argument has five distinctive virtues. First, it draws attention to an important but often overlooked factor, overlapping discrimination against citizens 
and refugees, that should both inform refugee policies and enter into our moral evaluations of these policies. Second, it captures the deep connection between discrimination against citizens and policies concerning non-citizens that regularly obtains, and that is currently manifested in the relationship between Islamophobia and the responses of many liberal societies to the Syrian refugee crisis. Third, it yields requirements that are consistent with even many of the strongest restrictionist views in the ethics of immigration literature, insofar as they claim to be liberal views or compatible with liberalism. Fourth, it avoids the need to establish that a society is responsible for, in some relevant sense, ${ }^{3}$ the fact that refugees have been displaced, which may be true in many cases but notoriously difficult to establish and account for when multiple actors and other causal influences have played a role. And fifth, the argument does not require taking a stand on the broader internalism-externalism debate regarding the causes of refugee crises in general to demonstrate that these duties hold.

\section{Discrimination Against Non-Citizens and Disrespect for Citizens}

Before offering this argument, it will be important to have some further preliminaries in place regarding equal respect and how policies that facially concern the treatment of refugees can manage to express disrespect for citizens. To start, the principle of equal respect, as I mentioned above, holds that a society's political institutions, policies, and members in their official capacities must treat all members of society with equal respect and, when applicable, must express equal respect for them. ${ }^{4}$ This is one interpretation of the principle and the one that I will be working with in the paper, focusing as I mentioned on its expressive component - the last conjunct of the principle. Other plausible interpretations of the principle may be given, and the 
choice between them and this one will not substantively affect my argument. It is worth noting that the principle of equal respect for members is a core principle of domestic justice and liberal political philosophy in particular (Dworkin 1978; Anderson 1999).

I also wish to remain neutral regarding how best to understand the notion of respect that operates in this principle, relying instead on an intuitive and shared judgment that immigration policies that target social groups can express disrespect for citizens in those groups. While I present a distinctive account of how immigration policies can target domestic groups, the question whether such policies are disrespectful in the first place is one that I take, for the purposes of this paper, to be settled. The distinct contribution of this paper turns not on establishing whether such policies disrespect citizens, but what follows regarding refugee policy if citizens are subject to other policies and practices that express disrespect for them.

To forestall one concern, I wish to acknowledge the difficulty that if respect is owed to all persons, as many philosophers have argued (see, e.g., Kant 1785/2012 and Darwall 1977), how can the principle of equal respect be restricted to members, and not extend to outsiders? As one might guess, I am sympathetic to this point. But for my purposes here, I need not defend anything as far reaching as a principle of equal respect for all persons that constrains societies' actions towards outsiders. I instead rely only on the widely-shared liberal principle of equal respect for members. My argument has the benefit of appealing to this more minimal requirement that even restrictionists working in the liberal tradition must endorse, where some would deny that the same standards of equal respect constrain liberal societies in their relations with non-citizens (Walzer 1983, Wellman 2008), or that non-liberal societies must accept a principle of equal respect for persons. 
Let's begin then by examining how a policy that concerns the treatment of non-citizens can express attitudes towards citizens, let alone disrespectful ones. What we're considering is the possibility of a sort of transference of disrespect, where X's expressing disrespect for Y entails that $\mathrm{X}$ has expressed disrespect for $\mathrm{Z}$. The possibility of this kind of disrespect relation obtaining in immigration first arises with Michael Blake's response to Michael Walzer's discussion of the White Australia policy (Walzer 1983; Blake 2003). In arguing for the view that the permissibility of immigration restrictions is an implication of a society's self-determination, Walzer holds that even the goal of having a homogenous white Australia could be permissible to implement in immigration policy, so long as Australia made its unused land available to others. Walzer's view is captured by his phrase "White Australia could survive only as Little Australia" (Walzer 1983, 47). In response to this claim, Blake suggests that the White Australia policy could be recognized as morally wrong even if we thought that no non-white person seeking to immigrate to Australia had a claim against the treatment it entailed, because there were nonwhite people present in Australia, indigenous Australians and others, whom this policy treated as second-class citizens. He goes on to conclude that in societies where "there are national or ethnic minorities - which is to say, the vast majority of actual societies - to restrict immigration for national or ethnic reasons is to make some citizens politically inferior to others" (Blake 2003, 233).

Blake's argument is insufficient to establish this claim, because a set of further conditions have to obtain in order for immigration policies to treat some citizens as less than equal. As Blake notes, societies where there are no national or ethnic minorities whatsoever will be permitted to use at least nationality and ethnicity as selection criteria, unless the nationality or ethnicity picked out to be excluded, for some reason, matched with that of the citizenry. 
Christopher Heath Wellman emphasizes this point in noting his reservations about viewing discriminatory immigration policies as not only morally problematic but morally impermissible (Wellman and Cole 2011, 150). Of course, it's hard to imagine many reasons why a fully homogenous society would attempt to exclude persons with the same nationality or ethnicity as the people already present. ${ }^{5}$

Further, even a diverse society may, as far as this argument shows, restrict immigration on the basis of these criteria if members of the relevant groups are not present. Additionally, not only must members of the group be present, but some other conditions must obtain, and one that typically obtains in the cases under discussion is that these citizens see the treatment of outsiders as their own treatment in some real sense. In other words, they identify with these persons (Lindauer 2017). Merely sharing a quality with other people, when that quality is the basis for exclusion, does not make it the case that one will take this treatment of others to express disrespect for oneself.

What we need to establish the relevant link between discriminatory immigration policies and violations of the principle of equal respect for members is an account of identification between citizens and non-citizens. ${ }^{6}$ Briefly, the account that I have developed elsewhere (ibid.) posits two jointly sufficient conditions, identification as and identification with. The identification as condition specifies that one actually does share some quality or qualities with another person or group of persons, i.e. identifies as a member of the relevant social group. I take the sharing of such qualities to be a sociological fact, e.g. that Ahmed the U.S. citizen and Fatima the Syrian refugee share the quality of being Muslims, not merely a psychological fact about how people happen to see themselves. As we know from several recent high-profile cases, people can sometimes be quite self-deceptive about their social group membership - that a white 
person merely psychologically identifies as a Black person doesn't make them Black, nor does it make it the case that the disrespectful treatment of Black people expresses disrespect towards them. It is also worth noting that identification as is not a necessary condition for this transference of disrespect to hold. This is because sometimes people may express disrespect for us by targeting people that they merely perceive us to share some quality or set of qualities with, as when a bigot verbally attacks a Mexican American with Islamophobic language on the basis of their having phenotypic traits that the bigot associates with Muslims. But in the cases we are interested in here, the identification as condition holds - citizens identify as possessing a quality that non-citizens also possess, and genuinely possess that quality. The identification with condition adds that, for the relevant kind of transference of disrespect to go through, citizens must identify with these non-citizens on the basis of sharing the quality with them that they are being targeted for possessing. Ahmed the U.S. citizen identifies with Muslim Syrian refugees in virtue of their sharing the quality of being Muslims, and sees discriminatory treatment of these refugees on the basis of their possession of this quality as expressing disrespect for him. It should also be clear, then, that I do not intend identification with in my sense to cover what might be called solidaristic identification with others, i.e. where we take a special interest in the harms that they suffer without plausibly seeing their treatment as our own. ${ }^{7}$ When both the identification as and identification with conditions hold, all else being equal, discrimination against another person on the basis of the relevant quality or qualities will express disrespect for ourselves.

It is also worth noting that my argument here will not depend on any particular view of what ultimately makes violating the principle of equal respect for members wrong. On some views, expressing attitudes incompatible with the equal status of members is wrong in itself 
(Anderson 1999, 2010; Anderson and Pildes 2000; Scanlon 2010; Hellman 2011), while others focus on the consequences that discrimination and denials of equal respect produce (Honneth 2007; Lippert-Rasmussen 2014). On any plausible account, discrimination against minority groups of the sort exemplified by Islamophobia will count as a moral wrong that the state has a responsibility to address. Nor am I committed to a particular view regarding why special rights or treatment for minority groups is an appropriate way of redressing failures to treat them as equals (see, e.g., Taylor 1989, 1992; Young 1990; Modood 1998; Galeotti 2002; Song 2005, 2007). I do, however, hold that a focus on expressive disrespect can help to illuminate the duties that societies have to their citizens concerning refugee policy.

\section{Domestic Discrimination and Refugee Prioritization}

Now we have the theoretical resources in place to diagnose the domestic wrongs that the refugee policies of liberal democracies often perpetuate against their Muslim citizens. First, in the most extreme cases where societies refuse to take in Muslim refugees altogether and are thus unwilling even to consider their requests for asylum, this policy is reasonably interpreted as expressing the attitude that Muslims are unwanted in society, including Muslims who are already present. Typically, this is accompanied by the attitude that Muslims are especially dangerous or threatening and unsuited to integration into a liberal society. These attitudes fit with the rhetoric that is often put forward in attempts to justify such refusals. The supposed policy goal of protecting the citizenry from Muslims notably overlooks the fact that this very policy wrongs Muslim citizens. And the broader view that Muslim refugees are unwanted, as noted, also implies that Muslim citizens are unwanted. These attitudes are incompatible with the principle 
of equal respect for members because they imply that Muslim citizens are not equal to other citizens, whose place in society is not called into question, and who are not regarded as dangerous or threatening merely on the basis of their faith. Notably, even someone who held that refugees are not wronged by refugee policies that express disrespect for them would be on the hook here, so long as they claim that their view is compatible with liberalism and, in particular, the principle of equal respect for members. ${ }^{8}$ And more moderate views which hold that it can be permissible to help refugees in other ways instead of taking them in, such as by giving more aid, if they are liberal views, must countenance the possibility that adopting these other means will be impermissible in instances where the attitude expressed by doing so is that Muslims are unwanted. All of this is fully compatible, so far, with the requirement that Muslim refugees be treated on a par with other refugees.

Further issues arise, however, when a society has a history, either longstanding or recent, of Islamophobia within its borders. Suppose that Muslims have been treated with suspicion and generally are not viewed as equal citizens, and that often this ill treatment of Muslims has been encouraged by xenophobic rhetoric targeting them, conditions that largely match real world cases. Under such conditions, a society is morally required to adopt forward-going policies to make it clear that Muslims, in particular, are welcome. When Muslims have been disproportionately affected by a refugee crisis, an appropriate way of doing so is to try to take in more Muslim refugees. Two main ways of doing so, which I will say more about, involve giving their claims extra weight in 1) choosing which asylum seekers who arrive at the state's territory to settle and 2) in choosing which refugees from other territories to resettle. There is a remedial duty to Muslim citizens to make up for the treatment they have experienced in society by becoming more welcoming to Muslims in general, and a policy that seeks to bring in more 
Muslim refugees through these two available means expresses a welcoming attitude towards them. This is the opposite sort of attitude - that Muslims are valued and wanted in society_ of the discriminatory attitudes that are part of the problem of Islamophobia in many existing liberal societies.

I focus on settling asylum seekers (hereafter "settlement") and resettlement because, in each case, states have choices with regard to which refugees wind up present in their borders. While states must not violate the principle of non-refoulement, i.e., by forcing them to return to a country where they are liable to be persecuted, states can enter into agreements with other states to resettle asylum seekers elsewhere. Part of the requirement that I'm putting forward, then, is that states like the U.S., where Islamophobia has been a serious problem, should give extra weight to the claims of Muslim asylum seekers who wish to settle in their territory, and not seek to resettle them elsewhere. ${ }^{9}$ In resettlement, by contrast, states determine which refugees identified by UNHCR as unable to remain in the current country where they are seeking protection to take in. Notably, only $1 \%$ of refugees recently have been considered for resettlement to one of a host of resettlement countries. My argument also implies that adopting a more welcoming stance towards Muslims involves giving extra weight to the claims of Muslim refugees when deciding among potential refugees to resettle in the state's territory.

I have highlighted the case of Muslim minorities in liberal democracies because it is an important and salient instance of a wider moral phenomenon that I wish to call attention to. ${ }^{10}$ My more general point is that for social group $\mathrm{G}$, where $\mathrm{G}$ is composed of both citizens and noncitizens of a liberal democracy, certain ways of treating citizens who are members of $\mathrm{G}$ can make it the case that giving preferential treatment in settlement and resettlement to refugees who are members of $\mathrm{G}$ is an appropriate way of partially discharging the society's remedial duties to 
citizens who are members of G. In particular, when (i) group $\mathrm{G}$ has been treated in that society as unwelcome and thereby less than equal and (ii) this disrespectful treatment is tied to xenophobia and expressive disrespect towards members of $\mathrm{G}$ who are refugees on the basis of their being members of $\mathrm{G}$, welcoming more refugees who are members of $\mathrm{G}$ is an appropriate way for that society to attempt to make up for (i) and (ii), partially fulfilling its remedial duties to citizens who are members of G.

Given my emphasis on expressive disrespect in the form of unwelcoming attitudes towards a social group giving rise to remedial duties to citizens in that social group, it is clear why condition (i) should hold. Condition (ii) is required because there are many cases where social groups are treated as unwelcome and less than equal in a society, but nonetheless that treatment has little to do with xenophobia or anti-refugee attitudes. I describe one case that I take to meet condition (i) but not condition (ii) below, the case of gay Americans and the discrimination they suffer in the U.S. that, while morally repugnant, has little to do with xenophobia or bias against refugees in particular. The particular expressive relation of making up for the treatment of members of $\mathrm{G}$ as unwelcome immigrants or outsiders doesn't seem to hold in this case. However, it would be fully compatible with my account if both conditions did hold in this case, and so gay refugees should also be given a special status in settlement and resettlement for this reason in addition to any other potential reasons, such as their being subject to greater vulnerability than other refugees.

Moreover, it is this expressive relation that the present paper points to. When members of a social group have been treated as unwelcome through the expression of xenophobia and anti-refugee attitudes, welcoming more refugees in the targeted group is a way of counteracting these attitudes, and thus partially fulfilling remedial duties generated by the discrimination 
suffered by citizen members of that group. Conditions (i) and (ii) constitute the view that there is a certain fit between discrimination towards insiders and outsiders in a particular social group that can make welcoming more refugees from that group appropriate as a form of moral redress.

It may be surprising that remedial duties to citizens can justify prioritizing settling and resettling certain refugees rather than others. Indeed, some theorists have been skeptical that cultural factors generally can be permissible to use in selecting which refugees to admit (Miller 2016). But it seems that this is largely because they have envisioned selection criteria being used to adjudicate among refugees on the basis of cultural fit or reasons for preferring one group to others. My view is not that societies should adopt a preference for Muslim refugees on these kinds of grounds, but rather that resettlement policy ought to, in some circumstances, involve the recognition of a wrong that must be righted in society. The existence of this wrong justifies giving some extra weight to the claims of Muslim refugees in settlement and resettlement.

Of course, the general idea of giving extra weight to certain people's claims in order to rectify injustice is nothing new. Perhaps the most familiar example of this idea in practice is the use of affirmative action policies to address ongoing discrimination towards minorities and women. Refugee policy has generally not been seen as an appropriate venue for redressing domestic injustice. However, there are at least three reasons to think that righting the kind of domestic wrong of discrimination exemplified by Islamophobia through refugee policy is especially fitting.

First, as I have mentioned, when the wrong done to Muslims has been perpetrated, in part, through discriminatory attitudes that deny that they are welcome, being welcoming going forward to Muslims has the right fit to serve as an apt response. This is not to say that a society shouldn't also take other steps to address discrimination against Muslims citizens. For instance, 
it may fund media campaigns to combat harmful propaganda targeting Muslims, and sponsor events that link Muslim families to the broader communities they live in as a way of bringing similarities to light. But taking these other steps is wholly consistent with reorienting settlement and resettlement policies in the way that I have suggested. In fact, as I note in Section 3, these other measures may be background conditions for successfully realizing the aim of making Muslims more welcome when giving them extra consideration in settlement and resettlement.

Second, when Islamophobia within a society is largely sustained by attitudes of distrust towards Muslim immigrants and refugees, it is especially appropriate to undermine such attitudes by taking a welcoming stance towards these persons. This helps to explain why other social groups that are being discriminated against domestically may not have to be given the same priority in refugee policy. While other means should surely be adopted to address forms of discrimination targeting other social groups, as I suggested above, it is not clear that homophobia, for example, is primarily sustained by discrimination towards gay immigrants and refugees. There may be other reasons to give some priority to gay immigrants and refugees, for instance if they faced greater vulnerability due to discrimination in refugee camps. But it is not clear that settling and resettling more gay refugees would be an especially appropriate way to address domestic homophobia. By contrast, the link between the discrimination faced by Muslims domestically and attitudes towards Muslim refugees makes welcoming more Muslim refugees an appropriate way of addressing domestic Islamophobia.

Of course, adopting this welcoming stance could be met with adverse reactions. Such a reaction was observed in the case of the increase in support received by the far right party "Alternative für Deutschland" in Germany, a development that was viewed as a consequence of anxieties surrounding Chancellor Merkel's welcoming policies towards refugees. Notably, this 
reaction was relatively short lived in Germany, and support for the AfD is now at a low point, partly due to the public's response to increasing extremism in the party. But to be clear, I am focused here on moral requirements on refugee policy rather than questions of political strategy. When discrimination against Muslims within a society is heavily shaped by xenophobia aimed at Muslims immigrants and refugees, compensating for this fact by making a special effort to settle and resettle more Muslim refugees is an appropriate response. This is compatible with enough being wrong in a society that other steps must be taken first for this response to be practically possible.

Third, we may consider the fact that it seems like a very bad state of affairs if only certain countries, many of which are Muslim-majority countries, tend to be welcoming towards Muslim refugees. Overall, the global state of affairs is better when such patterns are corrected for and refugees are seen as people in need who are welcome anywhere, rather than their being treated with hostility by many societies that have the ability to take them in. To correct for this general problem, societies in which Muslims face significant discrimination should take extra steps to welcome Muslim refugees and correct for this imbalanced state of affairs.

Each of these points suggests that many liberal societies have a remedial duty to their own Muslim citizens to give extra weight to the claims of Muslim refugees in settlement and resettlement. Righting the domestic wrong of Islamophobia will involve, I have argued, taking these steps to make Muslim refugees and Muslim citizens welcome. I will now turn to consider some of the additional implications of this argument and address some further potential objections. 


\section{Further Implications and Replies to Objections}

I noted above that my view has the distinctive benefit of capturing the deep connection that regularly obtains between discriminatory attitudes towards refugees and discrimination towards minority groups within a society. How a society views and treats outsiders is often a reflection of how insiders are viewed and treated. I am thus in agreement with David Miller's point that theories of immigration justice should not "treat immigrants as perfect strangers" (Miller 2016, 156). Miller accuses the view that there is a human right to immigrate of doing so by focusing only on very general claims that all human beings have against one another. ${ }^{11}$ Yet his own view is supposed to be consistent with viewing immigrants as "strangers in our midst," and doesn't seem to take into account the deep connections that our societies already have with immigrants and refugees. As I have emphasized, a state's refugee policies often have significant expressive content regarding the status of its own citizens. I am arguing that in the present context, Muslim citizens of liberal democracies are a group that has been unfairly maligned and subjected to wrongful discrimination that has often taken the form of anti-immigrant, xenophobic prejudice, directed at their very status as citizens. Under these conditions, I have argued, societies have remedial duties to Muslim citizens to go beyond refraining from excluding or dispreferring Muslim refugees and give extra weight to the claims of these refugees in settlement and resettlement. Such a view appropriately accounts for the fact that refugees are not strangers, and the link between domestic discrimination and refugee policies that regularly obtains in actual societies.

None of this should be taken to suggest that remedial duties to insiders cannot be outweighed by other factors in refugee prioritization. For instance, if another group of refugees 
were far worse off in terms of the fulfillment of their human rights, perhaps because they faced discrimination in refugee camps that exceeded that which Muslim refugees faced, this could be a reason to consider these cases equally, or even tip the scale towards prioritizing the resettlement of these other refugees. Yet small differences that do not cut across a salient threshold, it seems to me, will not outweigh these remedial duties - for instance, if the first group of refugees was only slightly worse off than a group of Muslim refugees and both had serious lacks of human rights fulfillment.

Nor does anything that I have said imply that the use of refugee resettlement to achieve domestic aims should go on interminably. Determining the relevant cutoff past which we will have fully addressed nearly any real-world injustice is a notoriously difficult task. My argument in this paper does not rest on a single answer to the question of where the cutoff lies in this case, but it seems to me that the straightforward answer that, all else being equal, we may stop using refugee policy to address domestic discrimination when such discrimination no longer exists is the correct one. This is because the remedial duties to citizens that refugee policy is being used to address are grounded in the fact that citizens face this discrimination. Of course, it will be difficult to empirically assess whether a given form of discrimination has been eliminated. But using the methods of the social sciences that are already employed in studying Islamophobia and other similar forms of discrimination, it should be possible to form a reasonable judgment about whether this cutoff has been met.

It may be objected that what I have said here is moot because a society like the United States won't change its policies towards refugees, which are heavily influenced, or so I have claimed in the case of the U.S., by Islamophobia. ${ }^{12}$ Whether the point is practically moot is one consideration, and I doubt that this is the case. Finding new ways to articulate what is wrong 
with existing policies presents us with the possibility that we will find arguments and framings that change some people's minds who stand to, either as individuals or (more likely) as parts of collectives, make a difference. Recent history shows that subtle changes in public political discourse can yield huge changes in the public perception of a problem, two recent examples being the \#MeToo campaign and the Black Lives Matter movement. So the fact that the Trump administration, for instance, would not have been moved by such arguments doesn't mean that the opposition to their Islamophobic policies would not have potentially found such arguments useful.

Even if we suppose that making this argument has few practical benefits, we should not confuse practical upshot with moral upshot. It is worth knowing what is morally right in order to understand what we owe to others. Many times this knowledge affects our actions in ways that are causally diffuse and not easy to trace to particular arguments or considerations. It would be strange to deny that we should care at all about how our ideas and thoughts affect action in the real world. But this doesn't commit us to thinking that only arguments and ideas that would have direct and clearly measurably practical effects are worth entertaining, particularly when it comes to arguments and ideas concerning our responsibilities to members of vulnerable and disadvantaged social groups.

Along similar lines, one might worry that my account has the negative consequence of exposing refugees, an already beleaguered and vulnerable group, to societies where Islamophobia is present and treating them as a means to fixing these societies' internal problems. In response to this concern, there are a few points worth making. First, any democratic society that actually adopted my view would probably be one in which Islamophobia was already recognized as a real problem. Muslim refugees would not just be plunked down in this sort of 
society without its citizens and institutions beings somewhat receptive to them and aware of the problem of Islamophobia. Further, besides the remaining remedial duties to Muslim citizens that need to be addressed, my argument provides additional reasons for a society to devote resources and energy towards combatting Islamophobia, for instance through public campaigns and programs to encourage a welcoming atmosphere for Muslims immigrants more broadly. After all, adopting a more welcoming attitude towards Muslims by letting in more Muslim refugees and then not doing anything further to create a hospitable environment for these refugees to live in is an inconsistent set of policy actions if the goal is to make up for the presence of Islamophobia in society. And lastly, it may be that refugees should have the right to a "no detriment" refusal if they suspect that they will be placed in a society where they will be subject to significant discrimination. Of course, this right to refusal may be hard for refugees to apply, given the difficult circumstances and constraints that they are subjected to. For this reason, it is a follow-on requirement of my argument that a society not treat these refugees merely as means to the end of domestic justice, giving them a secure and welcoming environment in which to seek refuge to the best of its ability. ${ }^{13}$

As mentioned earlier, my argument may have the practical benefit of avoiding difficult questions of causal responsibility for refugee crises. Making determinations of causal responsibility about these highly complex cases is generally very difficult, and hence relying on such determinations could result in inaction or delayed responses to events that require states to act quickly. For instance, while it does seem that the U.S. bears special responsibility for various aspects of the Syrian refugee crisis, it is difficult to assess precisely how this responsibility should be weighed against that of the Assad regime and other actors in determining the remedial duties of the U.S. to refugees in this case. Further, my argument doesn't require one to enter into 
the debate between internalists and externalists about the causes of refugee crises more generally. Internalists holds that factors within a state, and primarily that state's actions, are the primary reasons why a state produces refugees, whereas externalists hold that external factors, and especially external states, are the primary causes of refugee movement. ${ }^{14}$ Because it avoids the need to settle controversial issues surrounding the causal genesis of a given refugee crisis and the factors that contribute to refugee crises in general, my argument may have distinctive practical benefits. Of course, these practical benefits over arguments that rely on causal responsibility only obtain when a desired practical consequence of making each argument is to get societies to take in the same group of refugees. ${ }^{15}$ Nonetheless, avoiding contentious issues of causality in making the argument that these refugees should be taken in is a benefit worth noting.

It is also worth noting that my argument has interesting implications concerning private sponsorship of refugees. Patti Tamara Lenard convincingly argues that, while private sponsorship programs such as the Canadian Blended Visa Office-Referred (BVOR) Program can be morally justified, they should retain their link with government sponsorship and state-based programs and not place the primary responsibility for refugees on private citizens (Lenard 2016, ms). I find much to agree with in her work on this topic and my argument here interacts in an important way with hers. When a state has a remedial duty to its own citizens to take in certain refugees, it has even more reason not to place the primary responsibility for taking in these refugees on citizens. It may, of course, be a good and appropriate thing for citizens to contribute to the fulfillment of this collective duty. But there is extra reason in the case of a society like the United States to make sure that private sponsorship does not replace the state's commitment to taking in Muslim refugees as compared with a society like Canada, where the same kind of virulent Islamophobia is not present (or at least not to the same extent). 
It may, however, also be the case that insofar as a private sponsorship program will be effectual and contribute to changing societal attitudes, a society like the United States is morally required to implement such a program as part of its efforts to combat existing Islamophobia. So long as distrust towards outsiders has a large effect on trust and acceptance of people within a society who are Muslim, there is extra reason for that society to set up such a program, with the caveat that, as I have argued, the existence of the program should not replace the government's commitment to taking in Muslim refugees.

\section{Conclusion}

In this paper I have argued that one important factor that a society should take into account when settling and resettling refugees is whether and how the treatment of refugees and other outsiders impacts domestic groups. The view that I have offered distinctively captures the important connection between the wrongs that minority groups experience in many liberal societies and policies and attitudes towards members of these groups who have yet to enter these societies. Without having to establish claims about the causal factors that gave rise to a given refugee crisis, we can find a compelling rationale in liberal principles for giving extra weight to the claims of refugees whom disadvantaged minority groups identify with. In our current context, this argument may help us to better understand how refugee policies can have important consequences for Muslim citizens of liberal societies, and for the duties of liberal societies to these citizens. 


\section{Notes}

${ }^{1}$ See, e.g., Blake (2003) and Lindauer (2017).

${ }^{2}$ While I argue that giving preferential treatment to refugees in these groups is a fitting way for a society to adopt this more welcoming stance, I do not hold that doing so will fully discharge the relevant remedial duties that society has to its citizens. I note that my view is perfectly compatible with societies being required to do much more to address forms of discrimination that target both citizens and non-citizens in Sections 2 and 3.

${ }^{3}$ See Miller (2001) for a helpful discussion of the different types of responsibility that are relevant when assigning responsibility to individual and collective agents.

${ }^{4}$ Of course, if the distinction between disrespectful treatment and expressive disrespect cannot be sustained, this formulation of the principle will be redundant. But there is reason to think that there may be some cases of expressive disrespect that do not constitute disrespectful treatment. For instance, mocking someone who is not present in the privacy of one's home may express disrespect for that person, but it's not obvious that we should think of this as a case of disrespectful treatment. It seems less plausible that there are cases of disrespectful treatment that do not also involve expressive disrespect, although the primary wrongmaking feature may still be the treatment rather than what is expressed. For instance, intentionally knocking a person's grocery bag out of their arms treats them disrespectfully, and may also express disrespect for them, but it's primarily the former that makes the act wrong. Nothing important to the argument in this paper rides on these details of the relationship between disrespectful treatment and expressive disrespect.

${ }^{5}$ In the few scenarios one could imagine in which societies would implement such policies, it's not obvious that these policies would always express disrespect for citizens. For instance, a society that had been homogenous might seek to diversify its population by either preferring or exclusively taking members of other groups for some period of time, and it's not clear that any expressive disrespect towards citizens would be involved in either case. We could also imagine the more far-fetched case of a society consisting solely of people who disliked themselves. In terms of whether minorities have to be present for immigration policies to express disrespect for citizens, this might be a test case. After all, if we can express disrespect for ourselves, it's not clear why citizens, motivated by self-loathing, could not collectively express disrespect for themselves by refusing to let anyone with their same nationality or ethnicity in. I do not have the space to fully explore these cases here, but they do suggest that it is hard to draw any fully general rules about the criteria that can and can't be used by societies in immigration policy. As I will be arguing, religion can sometimes be used as a criterion, in ways that not only do not express disrespect for members, but in fact seek to make up for prior disrespect for them.

${ }^{6}$ I cannot offer a theoretical account of what specifically constitutes Muslim identity in this paper. Doing so would go well beyond the bounds of the present project. For two accounts, see Bilgrami (1992) and Fatima (2011).

${ }^{7}$ This is not to say that solidaristic identification may not be relevant in determining whether policies towards noncitizens express disrespect for citizens. I am grateful to an anonymous reviewer for pushing me to clarify this point. ${ }^{8}$ It is also worth noting here that because my argument in this paper depends on a liberal principle of domestic justice, it is not an implication of the argument that non-liberal societies are required to adopt refugee policies that redress domestic injustice.

${ }^{9}$ There is a parallel here to the argument made by Souter (2014) that states have a remedial duty to grant asylum to refugees when they are responsible for the flight of these persons from their country of origin. My argument instead focuses on the duties of states to grant asylum to refugees who are members of a social group that has been subject to discrimination in that state.

${ }^{10}$ I am grateful to an anonymous reviewer for pushing me to examine the relationship between this broader phenomenon and the case of Muslim refugees in more detail.

${ }^{11}$ Miller's main targets here are Carens (2013) and Oberman (2016). While I agree with Miller's point that immigrants should not be conceived of as "perfect strangers," I do not share his view that a human right to free movement necessarily does so. For instance, a human rights view that incorporates remedial duties of the sort that I am arguing for will recognize a morally significant tie of identification between citizens and non-citizens.

${ }^{12}$ Even if one were to dispute that this is the case in any particular country, my argument takes the form of a conditional - if there is a link between domestic discrimination and refugee policy of the kind that I have described, there will be remedial duties to insiders.

${ }^{13} \mathrm{I}$ am grateful to an anonymous reviewer for pushing me to address this issue.

${ }^{14}$ For a helpful overview of the internalism-externalism debate, see Souter (2014).

${ }^{15}$ I would like to thank an anonymous reviewer for emphasizing this point. 


\section{Acknowledgments}

I would like to thank Sarah Fine, Mollie Gerver, Siba Harb, David Miller, Kieran Oberman, Lea Ypi, and the audience at the Refugees and Minority Rights Conference at the University of Tromsø in June 2018 for helpful discussion of the ideas in this paper. For helpful written comments, I am grateful to Serene Khader, Kasper Lippert-Rasmussen, Annamari Vitikainen, and two anonymous reviewers for the journal.

\section{Disclosure statement}

No potential conflict of interest was reported by the author.

\section{Note on contributor}

Matthew Lindauer is Assistant Professor of Philosophy at Brooklyn College, City University of New York. His primary areas of research are moral and political philosophy, moral psychology, and experimental philosophy. His work has appeared in Philosophical Studies, Journal of Moral Philosophy, Journal of Ethics and Social Philosophy, and Oxford Studies in Experimental Philosophy, among other venues.

\section{References}

Anderson, E.S. (1999). What Is the Point of Equality? Ethics, 109(2), 287-337.

Anderson, E.S. (2010). The Imperative of Integration. Princeton, NJ: Princeton University Press.

Anderson, E.S., \& Pildes, R. H. (2000). Expressive Theories of Law: A General Restatement. University of Pennsylvania Law Review, 148(5), 1503-1575.

Bayrakl1, E., \& Hafez, F. (2018). European Islamophobia Report 2017. SETA.

Bilgrami, A. (1992). What is a Muslim? Fundamental Commitment and Cultural Identity. Critical Inquiry, 18(4), 821-842.

Blake, M. (2003). Immigration. In R. G. Frey \& C. H. Wellman (Eds.), A Companion to Applied Ethics (224-37). Malden, MA: Blackwell Publishing.

Carens, J.H. (2013). The Ethics of Immigration. New York: Oxford University Press.

Darwall, S.L. (1977). Two Kinds of Respect. Ethics, 88(1), 36-49.

Duffy, B. (2016). Perils of Perception. Ipsos MORI.

Dworkin, R. (1978). Taking Rights Seriously. Cambridge, MA: Harvard University Press.

Fatima, S. (2011). Who Counts as a Muslim? Identity, Multiplicity and Politics. Journal of Muslim Minority Affairs, 31(3), 339-353. 
Galeotti, A.E. (2002). Toleration as Recognition. Cambridge, UK: Cambridge University Press.

Hellman, D. (2011). When Is Discrimination Wrong? Cambridge, MA: Harvard University Press.

Honneth, A. (2007). Disrespect: The Normative Foundations of Critical Theory. Cambridge: Polity Press.

Kant, I. (1785/2012). Groundwork of the Metaphysics of Morals M. J. Gregor \& J. Timmermann (Eds.) (Revised Edition). Cambridge: Cambridge University Press.

Lenard, P. T. (2016). Resettling Refugees: Is Private Sponsorship a Just Way Forward? Journal of Global Ethics, 12(3), 300-310.

Lenard, P.T. The Ethics of Citizen Selection of Refugees for Resettlement. Unpublished ms.

Lindauer, M. (2017). Immigration Policy and Identification Across Borders. Journal of Ethics and Social Philosophy, 12(3), 280-303.

Lippert-Rasmussen, K. (2014). Born Free and Equal? A Philosophical Inquiry into the Nature of Discrimination. New York: Oxford University Press.

Miller, D. (2001). Distributing Responsibilities. Journal of Political Philosophy, 9(4), 453-471.

Miller, D. (2016). Strangers in Our Midst: The Political Philosophy of Immigration. Cambridge, MA: Harvard University Press.

Modood, T. (1998). Anti-Essentialism, Multiculturalism, and the 'Recognition' of Religious Groups. Journal of Political Philosophy, 6(4): 378-399.

Oberman, K. (2016). Immigration as a Human Right. In S. Fine and L. Ypi (Eds.), Migration in Political Theory: The Ethics of Movement and Membership (32-56). Oxford: Oxford University Press.

Scanlon, T. (2010). Moral Dimensions: Permissibility, Meaning, Blame. Cambridge, MA: Belknap.

Song, S. (2005). Majority Norms, Multiculturalism, and Gender Equality. American Political Science Review, 99(4): 473-1489.

Song, S. (2007). Justice, Gender, and the Politics of Multiculturalism. Cambridge: Cambridge University Press.

Souter, J. (2014). Towards a Theory of Asylum as Reparation for Past Injustice. Political Studies, 62(2), 326-342. 
Taylor, C. (1989). Sources of the Self: The Making of the Modern Identity, Cambridge, MA: Harvard University Press.

Taylor, C. (1992). The Politics of Recognition. In A. Gutmann (Ed.), Multiculturalism: Examining the Politics of Recognition (25-73). Princeton: Princeton University Press.

Walzer, M. (1983). Spheres of Justice: A Defense of Pluralism and Equality. New York: Basic Books.

Wellman, C. H. (2008). Immigration and Freedom of Association. Ethics, 119(1), 109-141.

Wellman, C. H., \& Cole, P. (2011). Debating the Ethics of Immigration: Is There a Right to Exclude? Oxford: Oxford University Press.

Young, I.M. (1990). Justice and the Politics of Difference. Princeton: Princeton University Press. 